DOI 10.22363/2313-2310-2018-26-3-367-378

UDC 556.3

\title{
Groundwater Management Protection Program for Nigeria
}

\author{
N.N. Kalu \\ Peoples' Friendship University of Russia (RUDN University) \\ 8 Podolskoe Shosse, bldg. 5, Moscow, 113093, Russian Federation
}

This article looks into groundwater pollution in Nigeria; groundwater uses and suggests how to go about protection of Nigeria's underground water. There were case studies of wells at different regions; content analysis indicated physical, chemical and organic factors with parameters that surpassed upper boundaries established by World Health Organization. The public full understanding of economic and social importance of underground water will help in Full integration of Comprehensive Regional Groundwater Protection Program for Nigeria.

Keywords: Nigeria, groundwater, quality and quantity, CRGWPP

\section{Introduction}

Groundwater protection programs are the point of convergence for a new collaboration and cooperation between Environmental Protection Agencies, various institutions and firms to achieve a more economical, systematic, competent, extensive and infinite approach to protecting groundwater resources. Ground water protection programs are crucial steps in implementing groundwater protection motives and principles.

Environmental Protection overall motive is to thwart, avoid and hinder adverse effects to human health and the environment, and to preserve the environmental integrity and purity of the world's Groundwater. Environmental protection will consider the use, value and vulnerability of the resource, as well as social and economic values. This signals for Groundwater Safeguarding Programs that certify protection of drinking water supplies, sustention and conservation of the environmental integrity of ecosystems related with groundwater. Correspondingly, environmental protection perspective should be defining appropriate prevention and protection policies, plans and approach.

Nigeria is not exempted in adopting a Comprehensive Regional Groundwater Protection Program (CRGWPP). Yearly rainfall fluctuates from over $4000 \mathrm{~mm}$ in the south to less than $250 \mathrm{~mm}$ in the north, the national average being $1180 \mathrm{~mm}$. Recent years have seen declining rainfall totals in Northern Nigeria and drought is a recurrent problem in the region. The mean yearly temperature in Northern Nigeria is around $25^{\circ} \mathrm{C}[1]$.

(C) Kalu N.N., 2018

This work is licensed under a Creative Commons Attribution 4.0 International License 
Nigeria is divided into 6 regions. Each is made up of different states as Nigeria is made of 36 states. Concerning the wide-ranging use of underground water, high importance, exposure to pollution, social and economic consequences of such exposure to contamination, it is important that groundwater is protected through the collaboration of Government, agencies and public.

\section{Regional Groundwater Protection Objectives}

\section{Inhibition of pollution whenever feasible}

To avert and avoid adverse effects to human health and environment, inhibit environmental decency, prevention of pollution must be the primary focus of the CRGWPP method.

Inhibition of pollution at any time feasible must be the primary focus of CRGWPP. If prevention of all discharges and pollutants to all groundwater is not possible. This should not be a reason to allow groundwater to be neglected or abandoned. There should be consideration for all groundwater resources. The exposure of the groundwater should help regulate the level of source control measures necessary to prevent pollution. The relative use, value and exposure of groundwater at different regions and location should be wellthought-out in conclusions concerning the siting of facilities or activities. Also, due to limited government personnel and financial resources, the use, value, and exposure of groundwater should be reasons in setting priorities for daily operations of relevant programs.

Discussion and deliberation of the risks and the benefits of activities that may bring about health issues and environmental concerns could result in prevention measures to those regions where groundwater are considered to have certain uses and values that, if not protected and conserved would bring about an unwarranted risk to human health or the environment now or future generations. Regions are encouraged to pursue prevention whenever possible.

\section{Remediation in which is based on both the comparative use and value of groundwater}

The prominence of groundwater protection ought to be on the inhibition of pollution. Remediation must be pursued as a final option when inhibition fails or where pollution already exists. Knowing the cost of cleaning up groundwater pollution and the necessity to concentrate on effort and resources on inhibition, National Environmental Standards and Regulations Enforcement Agency (NESREA), Nigeria Hydrological Services Agency (NIHSA) and the regions must take a specific realistic approach to a restoration based on reasonably expected usage of the resources and also that of social and economic values. It is important for the NESREA, NIHSA regions to work together in order to guarantee reliable methods to decide clean-up purposes

\section{Groundwater pollution is a national concern}

For many years groundwater was in general considered to be untouched resource. Experts and the public thought that the surface waters were certainly protected by layers of soil and earth and were purified naturally. Pollution was thought to occur results of septic systems operations. 


\section{Threats to groundwater}

A study on the groundwater pollution from abattoir waste located at Minna state. Carefully examined wells indicated physical, chemical and organic factors and parameters that surpassed upper boundaries established by World Health Organization (WHO). The waters are generally and mostly hard water which contained elevated concentrations of $\mathrm{CaCO}_{3}, \mathrm{MgCO}_{3}$, sulphates, nitrates, phosphates and heavy metals [2]. Overall of $194 \mathrm{~kg}$ of solid waste is generated and produced on a daily basis in Nsukka metropolitan abattoir, deprived of any sanitized and clean dumping and discarding or management approach and methodology. There are multiple and increased information of drinking water pollution in Nigeria [3]. As a result of exploration, investigation, examination, news reports, and studies, there has been an awareness that there are so many dangers and threats to groundwater which includes synthetic and artificial chemicals of so many categories and usages, together with synthetic organic compounds; fertilisers; pesticides; wastes from mineral and petroleum exploration, production, transportation, storage and usage; and pollution have all been detected. All these arise from underground storage tanks, surface sites, pesticides storage, mixing, and application sites, septic tanks, underground injection wells and variety of other sources.

\section{Effects and concerns of water pollution in Nigeria}

Most important effects and concerns of water contamination and pollution in Nigeria are health, ecological/environmental, socio-ecological problems. Nigerian government is suffering from terrifying and devastating cost inconsistencies. Contaminated or polluted water having residues, deposits and parasites is very costly to purify to wanted requirement for domestic and industrial use. This is also associated with the financial consequences of eliminating related illnesses. There by affecting children and infants, as can be seen from the high infant mortality rate in Nigeria. Adults are not excluded from suffering from poverty. The burden of malaria is vast and overwhelming enough to affect economic and social growth in Nigeria [4].

Water related diseases are the most common causes of illness and death, affecting mainly poor inhabitants in the local communities. Several cases have been reported. In October 2010, 29115 cases involving 1191 deaths of cholera had been reported in just 15 out the 37 states including Federal Capital Territory. The figure increased from 1616 and 1260 deaths in 2004. It was detected that the epidemic and occurrence is still in present in new neighborhoods and districts attributable to endless water pollution. Pond water equals more than $75 \%$ of total water used in Idere community of Oyo state. Pollution assessment and evaluation in the 80's made known no appropriate hygienic and healthy approaches for discarding of human waste, making the ponds the instantaneous objects exposure to these wastes. Intensity and concentration of pollution was linked with Guineaworm infections in the community. Polluted ponds were noticed and discovered to be the of the spread of this infection (Dracunculus medinensis), other parasites and bacterial infections [5]. Survey approved and supervised by World Health Organization indicated that about 96000 people had Guinea-worm infections in 1991, with Nigeria as one of the 13 African countries with unceasing drinking of polluted water.

The rural communities and areas have been responsible for the spread of disease and infections. May 2009, Society for Gastroenterology and Herpetology in Nigeria 
(SOGHIN) uncovered excessive occurrence frequency of hepatitis with 19 million people, regularly deprived people being infected. Hepatitis B and C continues to kill people and major hepatitis infections that are currently diagnosed in Nigeria. 2001, Rahman et al. gave details that, 1984 and 1999, 954 children underneath the age of 15 years were detected with typhoid fever in western region, of which 108 had puncture long-established at surgery. Statistical data estimates that about $52 \%$ of all documented cases of typhoid fever is in adults and children. Statements and details from different health institutions in Lagos state indicated serious situations of multi-drug resilient salmonella typhoid in teenagers between the ages of 16 and 30, with 635 occurrences diagnosed in less than 15 months that is from May 1997 to July 1998. Not long ago [6], give an account of an occurrence of 441 patients diseased from same illness in the same community. Matter of life and death is that most of the patients are diagnosed with other pollution diseases such as malaria, cholera. Poisoning as a result of heavy chemicals is a worrying health and environmental problem; most Nigerians give an account, which results from assimilation of polluted water or food. Not long ago [7] organized a study on 240 people, encompassing of children, pregnant/nursing women and men in Eastern Nigeria, Enugu state to be precise.

These elements nickel, manganese and chromium were uncovered with concentrations over and above the acceptable boundaries permitted by WHO, the blood tests of the respondents. The poisoning was largely understood to be water poisoning. In a connected occurrence, over 400 children from several communities roughly near Gummi and Bukkuyum local government areas of Zamfara state died of lead poisoning in six months in the year 2010. Medical specialists and professional's descriptions and statements from the state Ministry of Health and Medicines Sans Frontiers (MSF) defined the concerned children to reveal and disclose overwhelming and distressing symptoms for instance, gastro-intestinal aches, skin inflammations with rashes, fluctuations of mood; some were sluggish, partially paralyzed, become blind and deaf. The worst concerned victims came into the Ministry of Health with seizures that lasted for an hour and occasionally lead to coma and then to death. The poisoning which largely has a lot to do with mineral exploitation, pollution in water, food and air, have so far raised high level of concern for 3,600 children, with additional expectancies and anticipations that 180 communities sheltering up to 30,000 people may be influenced and involved with concern issues. Many of these occurrences can be seen today also in different Nigerian and international publications, the major concern remains how the problems could be fully addressed and resolved.

\section{Importance of groundwater in Nigeria}

Simultaneously as dangers to ground water came into being clearer and detected, the consequence and significance of protecting groundwater has also turn out to be obvious and well-defined, not just as a resource of which we get drinking water from. 95\% percent of the population of Nigeria gets drinking water from groundwater. $85 \%$ of the drinking water used in urban areas is gotten from groundwater resource, $75 \%$ of the consumable water in rural areas is gotten from groundwater.

$90 \%$ of the ground water exploitation and extractions in South-South region, South West, South East and North Central regions are mainly for used agronomic activities. In 
the South East, South-South and South Western regions, $40 \%$ of the groundwater exploitation and extractions is majorly used for industrialised purposes.

Importance of groundwater on ecological functions can't be over looked. There is an interconnection between groundwater and surface water. Annual streamflow in Nigeria is derived from groundwater, or baseflow. In humid zones, $80 \%$ of the stream flow is all gotten from groundwater. Intrinsic ground water ecology suggests that there are several species living organisms in groundwater, which leads to the conclusion there should be concerns about the quality of groundwater. Obviously, maintaining ecosystem and habitats are also importance of ground water.

\section{Groundwater quality and quantity}

\section{Groundwater level in Nigeria}

\section{Groundwater recharge}

The complete renewable groundwater resources capability and capacity in Nigeria is projected to be at least 155.8 billion cubic meters per year (BCM/year), obtained after calculated total annual groundwater recharge [8]. Water recharge fluctuates and differs throughout diverse regions in Nigeria, regulated and influenced basically by climate. In northern part of Nigeria, water recharge is very low as a result of low rainfall and high evapotranspiration.

The projected groundwater recharge at a regional level is expressed below (Table 1).

Table 1

The projected groundwater recharge at a regional level

\begin{tabular}{|l|c|}
\hline \multicolumn{1}{|c|}{ Region } & Estimated groundwater recharge (BCM/year) \\
\hline Niger North (Northwest Nigeria) & 5.0 \\
\hline Niger Central (West-Central Nigeria) & 20.5 \\
\hline Upper Benue (East-Central Nigeria) & 19.3 \\
\hline Lower Benue (East Nigeria) & 18.6 \\
\hline Niger South (South-Central Nigeria) & 31.9 \\
\hline Western Littoral (Southwest Nigeria) & 23.4 \\
\hline Eastern Littoral (Southeast Nigeria) & 32.8 \\
\hline Chad Basin (North-East Nigeria) & 4.3 \\
\hline Total & $\mathbf{1 5 5 . 8}$ \\
\hline
\end{tabular}

\section{Groundwater quantity}

Issues with drought keep leading to drop of groundwater levels, together with seasonal issues, in dry seasons, and all through elongated phases of low rainfall. This is predominantly a subject of matter for local, low storage basement aquifers, equally in the northern part of Nigeria where rainfall is at a low level and in the southern part, where rainfall is above average. The thinkable influence of climate alteration on groundwater levels, with altering climate patterns fused with changing water necessity, is acknowledged and known in the National Water Resources Master Plan. 


\section{Groundwater quality}

There is information about sea water intrusion into southern coastal aquifers accompanied with over extraction

There has been information with details of residential pollution of groundwater in the Lagos state by industrial chemicals all also associated with metal pollution of groundwater from mining activity (Ministry of Water Resources, 2013) (Table 2).

Table 2

Concluded trace-element data for ground waters from southern part of Nigeria [9] (All standards are in $\mu \mathrm{g} / \mathrm{l}, n=250$ (150 boreholes, 100 dug wells))

\begin{tabular}{|c|c|c|c|c|}
\hline Element & Minimum & Maximum & Mean & $\begin{array}{c}\text { WHO } \\
\text { guideline value }\end{array}$ \\
\hline $\mathrm{Al}$ & 22 & 270 & 94 & $200^{*}$ \\
\hline As & 0.40 & 6.9 & 1.9 & 10 \\
\hline $\mathrm{Ba}$ & 9.48 & 1150 & 420 & 700 \\
\hline $\mathrm{Br}$ & 41 & 210 & 95 & \\
\hline $\mathrm{Cd}$ & 0.06 & 1.1 & 0.27 & 3 \\
\hline Cs & 0.09 & 3.7 & 0.61 & \\
\hline $\mathrm{Cr}$ & 0.18 & 9.1 & 1.1 & 50 \\
\hline Co & 0.09 & 6.1 & 0.60 & \\
\hline $\mathrm{Cu}$ & 0.23 & 54 & 9.3 & 2000 \\
\hline $\mathrm{Pb}$ & 0.61 & 14 & 2.8 & 10 \\
\hline $\mathrm{Mn}$ & 1.4 & 290 & 55 & 500 \\
\hline Mo & 0.90 & 30 & 4.1 & 70 \\
\hline $\mathrm{Ni}$ & 0.80 & 37 & 5.2 & 20 \\
\hline $\mathrm{Rb}$ & 1.8 & 530 & 68 & \\
\hline $\mathrm{Se}$ & 2.3 & 22 & 7.1 & 10 \\
\hline Sn & 0.23 & 1.5 & 0.59 & \\
\hline $\mathrm{Sr}$ & 23 & 150 & 76 & \\
\hline V & 0.27 & 2.8 & 1.2 & \\
\hline $\mathrm{Zn}$ & 8.6 & 1700 & 100 & 3000 \\
\hline
\end{tabular}

* aesthetic, rather than health based, value.

\section{Groundwater organization and management institutions in Nigeria}

Lots of bodies are in authority with responsibility for groundwater organization and management in Nigeria. They consist of the government agencies:

1. Nigeria Hydrological Services Agency (NIHSA) is in authority for water resources (groundwater and surface water) estimation and evaluation; groundwater quantity, quality, availability and distribution in time and space.

2. Nigeria Integrated Water Resources Management Commission (NIWRMC) is in authority for regulation of water use and allocation.

3. National Water Resources Institute (NWRI) is in authority for promote and develops training courses in water resources. Promote necessary codes of practice in water resources development and management suitable for Nigerian conditions. 
4. Gurara Management Water Authority (GMWA) is in authority for invitation for technical and financial bids for the implementation of 2016 Capital Appropriation in compliance with the Public Procurement Act 2007.

\section{Professional Organizations}

Nigerian Association of Hydrogeologists (NAH) [10] is in authority for inspection, improvement, development and organisation of Nigeria's water resources. NAH spreads out information and data of condition of Nigeria's water resources by annual summits. National Technical Committee on Water Resources (NTCWR), National Council of Water Resources (NCWR), and NAH influences and impacts to the development of water resources policies and legislation, together with the Water Resources Act 100 and the Nigerian Standard for Drinking Water Quality.

\section{Legal framework for groundwater management}

Management, instructions and parameters with guideline have been established, as well as the Water Resources Decree 101 propagated in 1993 (present day referred to as Water Resources Act 100).

\section{Groundwater Monitoring}

Nigeria Hydrological Services Agency is in authority for groundwater monitoring. Nigeria has National Groundwater Level Monitoring Programme with 43 monitoring points, 32 of which are set up with data loggers. These are located in basement and sedimentary aquifers. The regularity of observation at sites with data loggers is every day and every so often twice daily.

NIHSA realized a programme of drilling new monitoring boreholes for monitoring groundwater level. The new boreholes are concentrated on sedimentary aquifers utilized for urban water supply; with borehole penetration of 80 to $100 \mathrm{~m}$. Groundwater level monitoring information and data are kept at NIHSA head office.

\section{Groundwater designed for future}

Groundwater conceivably will influence increase in expectations of water demand in future. Modernization of existing borehole installation and substructure, substituting hand pumps to power-driven pumps.

During the project to modernize Nigeria’s Water Resources Master Plan, uncovered issues that influenced generation and quality of groundwater in Nigeria:

- unjustifiable and unnecessary oversimplification of water level deterioration;

- pollution of groundwater from sea water encroachment and penetration of domestic and industrial pollutants.

Stipulated and proposed that climate alteration will lead to a decline in groundwater recharge in Nigeria; utmost consequence will be in the northern part of Nigeria and Chad basins. Declining groundwater heights would take place, leading to functioning boreholes becoming dry. 


\section{CRGWPP as the focus of a new federal/state/regional partnershiping on groundwater protection}

CRGWPPs are projected, planned, proposed and anticipated to make up and develop what we have been educated on about groundwater protection and remediation. CRGWPP approach and methodology conjoins many of the lessons learnt directly into CRGWPP activities and pursuits. When there are limitations to federal and state laws to successfully and productively uphold the lessons learnt from groundwater protection and remediation, the CRGWPP approach/methodology will support and uphold all necessary changes in existing and emerging laws, regulations, and policies essential to address the remaining lessons.

\section{Henceforth, CRGWPPs will uphold the following:}

Prevention. A regional ambition should be on preventing ground water pollution. States and regions are encouraged to consider the relative exposure of ground water in defining necessary prevention procedures and consider the comparative use and value, as well as exposure of groundwater when determining where to position potential pollution sources.

NESREA and other government agencies are required to identify, uncover the economic and social influences of prevention measures. They may need to be evaluated against the use and value of specific and restricted groundwater resources. Nevertheless, prevention and reduction of pollution are supposed to be the main concern of each region CRGWPP, some level of protection ought to be taken into consideration for all ground waters in a region and state.

Regions and states ought to give some level of authorization or give the go-ahead order to local governments or local authorities to determine and conclude on what is competent for preventing groundwater pollution in rural areas and low populated towns of Nigeria. Federal standards and regulations will still be followed when stipulating and specifying what is achievable and feasible. A region and state's goal is required to be grounded on non-degradation or anti-degradation. NESREA and other agencies had better acknowledge that it might get to a point where there will be occasional rise for harmonizing economic and social costs of prevention against groundwater use and value. Conclusions and resolutions should conserve, support and safeguard resources for future generations.

Remediation. A region and state's aim/target is required to be fully grounded on groundwater that are hydrologically connected to surface waters for drinking water. Reduction of pollution on ground waters which are hydrologically connected and linked to surface waters so that its discharge to surface water does not go beyond water quality standards and guidelines. A state's and region's target and objective for cleaning of polluted groundwater possibly will also be grounded on "relative risk to human health and the environment.

Program organization. The CRGWPP method and methodology will make certain programs work with respect to its aims and purposes in a coordinated conduct. Actions of several programs that influences ground water, directly or indirectly, cross-purposes, leading to confusion and inefficient expenses of efforts. Combining all programs and pursuits through a regional-directed, resource-based approach, a CRGWPP has to reduce or eliminate such situations. Regions and states will collaborate with NESREA and other agencies in designing and implementing programs to protect the resource. 
Increased recognition and identification of the interrelationship between groundwater quantity and quality. States should be encouraged to coordinate their groundwater quality and quantity objectives, particularly in maintaining aquatic habitats.

Public participation and support. CRGWPP mandated develop public understanding of the ground water protection related complications and problems. Every region and state should offer an all-encompassing means for public participation and support. This will enhance better understanding for addressing concerns, of social and economic environmental implications. CRGWPP highlights public participation will help gain public support for state ground water protection decision-making.

\section{What will make-up \\ a Comprehensive Regional Groundwater Protection Program}

A Comprehensive Regional Ground Water Protection Program is made up of a set of four strategic activities which relatively are more efficient and effective in protection of groundwater. Harmonized operation of all relevant federal, state, and local programs within a region and state. The four strategic activities are:

- instituting a groundwater protection aim and priority to influence and recognize sources of pollution, and programmatic needs in all related federal, state, and local programs operating within a region and state;

- determining roles, responsibilities, and managing system sources, of all federal, state, and local programs for focusing on recognized groundwater protection priorities. instigating all that is essential to achieve regional groundwater protection aim;

- improving public education and participation in all aspects of groundwater protection to achieve support of the state's protection aim, priorities, and programs. Planning is compulsory in creating and affecting these strategic activities, a plan does not by itself make up a CRGWPP. The strategic activities of a CRGWPP are meant to influence all groundwater connected programs within the region;

- information awareness is creating enormous computer databases to gather and store the information including e-mails, social networks, phone calls, medical records, and numerous other sources.

\section{Relation to federal agency programs and other agencies}

CRGWPP methodology will be a very effective and efficient guard to Nigeria's groundwater resources centered on a resource-oriented decision-making process. CRGWPP approach will offer a considerable medium for improved state flexibility and management including policymaking under many federal programs. This helps and makes sure states can concentrate efforts on protection to convene their distinctive groundwater protection requirements and main concerns. The CRGWPP methodology will realize these advantages by relating different federal programs into a partnership with the states.

CRGWPPs offer a basis for groundwater protection endeavors and activities for both federal, state and local; all can be properly managed and organized. This management and organization will decrease excessive repetition of effort and bring about use of program resources to address groundwater protection needs within a region and state. 
CRGWPPs provide the groundwork for state-directed and regional instituted, resourcebased main concerns. Environmental protection agencies will work together to adopt a reliable methodology to state groundwater policymaking across all relevant federal programs and guidelines. This will lead to increases in state tolerance to various federal programs; through pursuit of CRGWPP a state will realize full, reliable, technique to address its groundwater protection priorities in all related programs. Chapter 4 focuses on how CRGWPPs put regions and states in the lead position of making resource-oriented conclusions about groundwater protection endeavors.

\section{Conclusion}

Pollution can minimize right to use safe and reliable supplies. Monitoring of Nigeria's groundwater by NIHSA has uncovered that activities on the land have polluted and exposed, surficial aquifers impurities and pollutants. Moreover, naturally occurring pollutants and impurities are also found in Nigeria's groundwater in different geopolitical regions of the country. These pollutants consist of arsenic, manganese, fluoride and others as earlier explained.

Regarding to human health, the environment and legal policies, it is important for the Federal Government of Nigeria, Federal Ministries, State Government, State Ministries, local governments, local authorities and all environmental protection agencies to be strict with laws on disposal of sewage waste, municipal waste and monitor activities at abattoirs in all geopolitical regions. Recommending approaches and activities to protect groundwater degradation from pollutants and impurities, it is essential to think of the fact that groundwater and surface waters are part interconnected. Enhancements are required in principles and guidelines to handle more pollutants, and advance protection procedures to meet up with legal requirements, which might involve extra funding.

The public full understanding of economic and social importance of underground water will help in full integration of Comprehensive Regional Ground Water Protection Program. Estimated cost of cleaning up one groundwater site is $\$ 1100000$. In most cases, due to complexity of contaminants and geological characteristics cleanup is difficult. Nigeria’s Yearly budget is estimated at \pm N150 $000000000 \sim \$ 392000000$. The complete removal of contaminants from groundwater at possibly thousands of complex sites in Nigeria is unlikely, and no technology innovations appear in the near time horizon that could overcome the challenges of restoring contaminated groundwater to drinking water standards.

Regional and state programs on protection of groundwater must be strengthened to guarantee that safe and satisfactory water supplies are accessible to meet growing demands. Increased data collection and management for better decision making and planning related to groundwater use, ought to be among the top priorities for funding by Federal Government and Federal Ministries.

\section{References}

[1] Alagbe. (2002). Groundwater resources of river Kan Gimi Basin, North-Central Nigeria. Retrieved from: https://link.springer.com 
[2] Chukwu, O. (2008). Analysis of Groundwater Pollution from Abattoir Waste in Minna, Nigeria. Retrieved from: https://www.medwelljournals.com/abstract/?doi=rjdsci.2008.74.77

[3] Nwanta, J.A., Onunkwo, J., Ezenduka, E. (2010). Analysis of Nsukka metropolitan abattoir solid waste and its bacterial contents in south eastern Nigeria: public health implication. Retrieved from: https://www.ncbi.nlm.nih.gov/pubmed/20146999

[4] Jimoh, A. (2010). Malaria burden and the effectiveness of malaria: a Case Study of Asa Local. Retrieved from: http://www.iiste.org/

[5] Ilegbodu, V. (PubMed Journals). Source of Drinking Water Supply and Transmission of Guinea Worm Disease in Nigeria. Retrieved from: https://www.ncbi.nlm.nih.gov/labs/articles/2972262/

[6] Akinyemi. (2007). Diversity and antimicrobial resistance of Salmonella enterica. Retrieved from: http://www.sciencedirect.com/science/article/pii/S2215153214000142

[7] Okoye, C.I. (2010). High Levels of Heavy Metals in Blood of the Urban Population in Nigeria. Retrieved from: http://scialert.net/abstract/?doi=rjes.2010.371.382

[8] (JICA), J.I. (2014). The project for review and update of Nigeria national water resources master plan. Vol. 2. Retrieved from: http://earthwise.bgs.ac.uk/index.php/Hydrogeology_of_Nigeria

[9] Asubiojo. (n.d.). Trace Elements in Drinking and Groundwater Samples in Southern Nigeria. Retrieved from: https://www.ncbi.nlm.nih.gov/labs/articles/9496643/

[10] NAH. (n.d.). Nigerian Association of Hydrologists. Retrieved from: http://www.nah-nigeria.org/

Article history:

Received: 15.08 .2018

Revised: 15.09 .2018

For citation:

Kalu N.N. Groundwater management protection program for Nigeria. RUDN Journal of Ecology and Life Safety. 2018;26(3): 367-378. DOI 10.22363/2313-2310-2018-26-3-367-378

\title{
Bio Note:
}

Nwankwo Nnabueze Kalu - postgraduate student, Applied Ecology Department, Ecological Faculty, Peoples' Friendship University of Russia (RUDN University). Contact information: tel.: +7 (495) 952-89-01

\section{Программа защиты и управления грунтовыми водами Нигерии}

\author{
Н.Н. Калу \\ Российский университет дружбы народов \\ Российская Федерация, 113093, Москва, Подольское шоссе, д. 8, корп. 5
}

В статье рассматриваются загрязнение и использование подземных вод в Нигерии, предлагаются способы их защиты. Были проведены исследования скважин в разных регионах; анализ содержания проб выявил физические, химические и органические факторы с параметрами, превышающими верхние границы, установленные Всемирной организацией здравоохранения. Понимание общественностью экономической и социальной важности подземных вод поможет полной интеграции Комплексной региональной программы защиты подземных вод (CRGWPP) в Нигерии.

Ключевые слова: Нигерия, подземные воды, качество и количество, CRGWPP 


\section{Список литературы}

[1] Алагбе. Подземные водные ресурсы реки Кан Гими, Северо-Центральная Нигерия. 2002. URL: https://link.springer.com (дата обращения: 15.06.2018).

[2] Чукву O. Анализ загрязнения подземных вод от отходов скотобойни в Минне, Нигерия. 2008. URL: https://www.medwelljournals.com/abstract/?doi=rjdsci.2008.74.77 (дата обращения: 15.06.2018).

[3] Nwanta J.A., Onunkwo J., Ezenduka E. Анализ твердых отходов муниципальной скотобойни в Нсукке и их бактериального состава на юго-востоке Нигерии: значение для общественного здравоохранения. 2010. URL: https://www.ncbi.nlm.nih.gov/pubmed/20146999 (дата обращения: 15.06.2018).

[4] Джимох A. Бремя малярии и эффективность малярии на примере Asa Local. 2010. URL: http://www.iiste.org/ (дата обращения: 15.06.2018).

[5] Илегбоду В. Источник питьевого водоснабжения и передача болезни гвинейского червя в Нигерии. URL: https://www.ncbi.nlm.nih.gov/labs/articles/2972262/ (дата обращения: 15.06.2018).

[6] Акиными. Разнообразие и устойчивость к противомикробным препаратам Salmonella enterica. 2007. URL: http://www.sciencedirect.com/science/article/pii/S2215153214000142 (дата обращения: 15.06.2018).

[7] Окой Ч.И. Высокий уровень содержания тяжелых металлов в крови городского населения Нигерии. 2010. URL: http://scialert.net/abstract/?doi=rjes.2010.371.382 (дата обращения: 15.06.2018).

[8] (JICA), J.I. Проект по пересмотру и обновлению генерального плана по водным ресурсам Нигерии. Т. 2. 2014. URL: http://earthwise.bgs.ac.uk/index.php/Hydrogeology_of_Nigeria (дата обращения: 15.06.2018).

[9] Асубихо. (н.о.). Микроэлементы в пробах питьевой и подземных вод на юге Нигерии. URL: https://www.ncbi.nlm.nih.gov/labs/articles/9496643/ (дата обращения: 15.06.2018).

[10] NAH. (н.о.). Нигерийская ассоциация гидрологов. URL: http://www.nah-nigeria.org/ (дата обрашения: 15.06.2018).

\section{История статьи:}

Дата поступления в редакцию: 15.08.2018

Дата принятия к печати: 15.09.2018

\section{Для цитирования:}

Kalu N.N. Groundwater management protection program for Nigeria (Программа защиты и управления грунтовыми водами Нигерии) // Вестник Российского университета дружбы народов. Серия: Экология и безопасность жизнедеятельности. 2018. Т. 26. № 3. С. 367-378. DOI 10.22363/2313-2310-2018-26-3-367-378

\section{Сведения об авторе:}

Калу Нванкво Ннабуэзе - аспирант, кафедра прикладной экологии, экологический факультет, Российский университет дружбы народов. Контактная информация: тел.: +7 (495) 952-89-01 